\title{
TPO/TPD study on the activation of silica supported cobalt catalyst
}

\author{
Hamid Al-Megren • Haoyi Chen • Yu Huang • \\ Mohammad AlKinany $\cdot$ Peter P. Edwards • \\ Tiancun Xiao $\cdot$ Yibo Wang
}

Received: 20 March 2013/Accepted: 7 May 2013/Published online: 8 June 2013

(C) The Author(s) 2013. This article is published with open access at Springerlink.com

\begin{abstract}
Silica supported cobalt catalysts have been prepared using urea containing cobalt nitrate solution impregnation method, which can give high loading $\mathrm{Co}_{3} \mathrm{O}_{4}$ with relatively smaller crystallite size. Compared to the conventional impregnation method, the catalyst prepared with urea added to the cobalt nitrate solution provides higher activity for $\mathrm{CO}$ conversion and $\mathrm{C}_{5}{ }^{+}$selectivity. To optimize the catalyst activation and simulate the industrial activation, TPO-TPR cycle treatment with or without steam has been applied to the prepared catalysts under various conditions. It is shown that reduction of pure hydrogen with high flow rate leads to a sharp temperature rise in the catalyst bed, which results in the sintering of the cobalt particles. A slow temperature rise with dilute hydrogen helps stabilize the cobalt particles, and the cycle treatment of the catalyst using TPO-TPR without steam induction has little effect on the size of cobalt particles. When steam is included in the reduction stream with hydrogen the TPR-TPO cycle treatment can help increase
\end{abstract}

H. Al-Megren · M. AlKinany

Petrochemical Research Institute, King Abdulaziz City for

Science and Technology, P.O. Box 6086, Riyadh 11442,

Saudi Arabia

P. P. Edwards · T. Xiao ( $\square)$

KOPRC, Inorganic Chemistry Laboratory, Oxford University, South Parks Road, OX1 3QR Oxford, UK

e-mail: xiao.tiancun@chem.ox.ac.uk

H. Chen · Y. Huang $\cdot$ T. Xiao

Guangzhou Boxenergy Technology Ltd, Guangzhou,

People's Republic of China

Y. Wang

Department of Chemistry, University of Alberta, Edmonton, Canada the Co dispersion, which increases the catalyst activity and selectivity to $\mathrm{C}_{5}{ }^{+}$.

Keywords Supported cobalt catalyst - Fischer tropsch synthesis · Urea combustion · TPR-TPO

\section{Introduction}

Research on alternative fuels plays an important role in emission reduction and future energy supply. FischerTropsch synthesis possesses the ability to convert carbon containing sources such as coal, natural gas and biomass into a cleaner and more economical alternative to traditional commercial fossil fuel [1-3]. Many years-operational experiences have shown that the use of FischerTropsch catalyst affects the economy of the whole process significantly. Therefore many researches have been undertaken to develop an efficient FTS catalyst, to refine the catalyst for the optimal activity [4-6]. Cobalt-based catalysts appear to provide the best compromise between performance and cost for the synthesis of hydrocarbon from syngas derived from coal, natural gas or biomass [7-13].

It has been demonstrated that metallic Co particles formed on the catalyst surface under FTS conditions are the origin of their catalytic activity for hydrocarbon formation [9, 13-17]. The supports for this process are primarily silica, alumina and titania, over which the active metal particles, e.g., cobalt, are dispersed. Co-based FTS catalysts are usually prepared by impregnating aqueous $\mathrm{Co}\left(\mathrm{NO}_{3}\right)_{2} \cdot 6 \mathrm{H}_{2} \mathrm{O}$ solution onto the support materials followed by drying and calcination. The impregnated $\mathrm{Co}$ nitrate is decomposed to $\mathrm{Co}_{3} \mathrm{O}_{4}$ and these precursor oxides are reduced with $\mathrm{H}_{2}$ to $\mathrm{Co}^{0}$ particles prior to FTS.

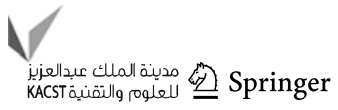


Recently, there have been studies showing that the activation procedure such as redox treatment can increase the catalyst performance.

On the other hand, there have been many efforts to make more uniform, stable and small $\mathrm{Co}_{3} \mathrm{O}_{4}$ particles over the support. These methods include the adaptation of calcination procedures and new Co precursors $[14,18,19]$. It is reported that Co oxalate and a mixed salt of Co nitrate and $\mathrm{Co}$ acetate as precursors give rise to smaller $\mathrm{Co}^{0}$ particles over the support [20]. However, the use of these precursors produced significant amounts of Co silicate-like species simultaneously, which were hardly reduced to the metallic state under normal conditions. Therefore, reducibility of Co was suppressed greatly, resulting in only weak activity enhancements.

To give a higher Co loading with better dispersion, chelating agents with multi-impregnation steps have been studied, which can give high Co loading with relatively small Co particles. However, this process is time consuming and difficult to scale up. Recently we have developed a novel method, which is to use the minimum amount of water and urea to form a Co nitrate containing aqueous organic solution. The feature of this solution is that it has high stability and high Co content, which easily leads to high Co content in the resulting catalysts [18, 21-26].

In this work, we prepared silica supported cobalt catalysts using the urea-cobalt nitrate hydrate system and silica support, and also the conventional aqueous impregnation method for comparison. The catalysts have been tested and characterized using various techniques, and their performances have been compared. The catalyst activation method on the chemical and physical properties of the urea-assisted dispersed catalyst has been explored [20, 27, 28].

\section{Experimental setup}

\section{Catalyst preparation}

The catalyst has been prepared according to the process described in the patent [29]. High surface silica (Fumed silica, Industrial Grade, Aldrich) is used as the support. Due to the nature of the fumed silica, it is wetted with very dilute $\mathrm{Al}\left(\mathrm{NO}_{3}\right)_{3}$ (analytical grade, Aldrich)/ $\mathrm{HNO}_{3}$ solution $(0.001 \mathrm{M})$ to form a paste and dried at $350{ }^{\circ} \mathrm{C}$. This support was used in all the experiments. The active metal comes from Co nitrate. The urea-cobalt melt solution is prepared as follows:

$\mathrm{Co}\left(\mathrm{NO}_{3}\right)_{2} \cdot 6 \mathrm{H}_{2} \mathrm{O}$ (Alfa, analytical grade) was mixed with $\mathrm{ZrO}\left(\mathrm{NO}_{3}\right)_{2} \cdot 2 \mathrm{H}_{2} \mathrm{O}$ (Alfa, Chemical Grade) $(\mathrm{Co}: \mathrm{Zr}=10: 1$, atomic ratio), and urea was added in a 4:1 ratio of urea to cobalt metal; the resulting mixture was then heated to $60{ }^{\circ} \mathrm{C}$ and stirred. The main action of zirconia is to reduce the cobalt reduction temperature as shown in the literatures [30-32]. A minimum amount of water $(2.0 \mathrm{ml})$ was added to the mixture to make a solution. The cobalt nitrate and zirconium nitrate were dissolved completely after stirring for $3 \mathrm{~h}$ at $60{ }^{\circ} \mathrm{C}$, the mixture was assumed to be homogeneous, and then the dried fumed silica (surface area $605 \mathrm{~m}^{2} / \mathrm{g}$; particle size $250-350 \mu \mathrm{m}$ ) was added to the solution for $24 \mathrm{~h}$. The mixture was stirred to allow the support to contact the solution. The mixture was heated at approximately $50{ }^{\circ} \mathrm{C}$ to vaporize the excess water in the mixture. It was then transferred to a quartz boat and calcined at $350{ }^{\circ} \mathrm{C}$ in static air for $10 \mathrm{~min}$. The resulting black particles were the catalyst precursors with a cobalt loading of $28.0 \mathrm{wt} \%$ over the silica support. The material prepared in this way is denoted as $\mathrm{Co} / \mathrm{SiO}_{2}-\mathrm{ZrO}_{2}$-urea.

For comparison, the non-urea added silica supported Co catalyst was prepared by incipient wetness impregnation of aqueous cobalt nitrate and zirconium oxy-nitrate in the fumed silica support, the system is placed in static air for $6 \mathrm{~h}$ at ambient temperature, and then dried at $200{ }^{\circ} \mathrm{C}$ for $4 \mathrm{~h}$ and calcined at $350{ }^{\circ} \mathrm{C}$ for $4 \mathrm{~h}$ to get a supported cobalt catalyst [33, 34]. To increase the cobalt content, the calcined sample is re-impregnated with the $\mathrm{Co}$ and $\mathrm{Zr}$ nitrate solution. The same treatment process was repeated to prepare the catalyst with $\mathrm{Co}_{3} \mathrm{O}_{4}$ loading up to $28.0 \mathrm{wt} \%$. The catalyst prepared using this method is denoted as $\mathrm{Co} /$ $\mathrm{SiO}_{2}-\mathrm{ZrO}_{2}-\mathrm{IC}$.

\section{Catalyst tests}

In the catalyst evaluation, $0.4 \mathrm{~g}$ (in powder form) was loaded in a $9 \mathrm{~mm}$ (OD $6 \mathrm{~mm}$ id) quartz tube. A stream of $\mathrm{H}_{2}$ (99.9\% from Air Products) flow was passed through the catalyst at a GHSV of 5,000-8,000 $\mathrm{h}^{-1}$ under atmospheric pressure before reaction. The temperature ramp rate was $1{ }^{\circ} \mathrm{C} / \mathrm{min}$ to $400{ }^{\circ} \mathrm{C}$ and held for $2-4 \mathrm{~h}$, then cooled to $225{ }^{\circ} \mathrm{C}$, at which the syngas $\left(\mathrm{H}_{2} / \mathrm{CO}=2\right.$, with 5 vol\% $\mathrm{N}_{2}$ as the internal standard, supplied by Air Products) was conducted into the reactor. The activity test was started under high pressure ( $\sim 8$ bar). The duration of the reaction depends on the catalyst performance, but would not be longer than 20 days. The exit gas was sampled every $30 \mathrm{~min}$ and analyzed using an on-line GC (Aglient 5890).

\section{Catalyst characterization}

TEM measurements were carried out on a JEOL 2010 analytical electron microscope, which had $\mathrm{LaB}_{6}$ electron gun and could be operated between 80 and $200 \mathrm{kV}$. This instrument had a resolution of $0.19 \mathrm{~nm}$, an electron probe size down to $0.5 \mathrm{~nm}$ and a maximum specimen tilt of $\pm 10^{\circ}$ along both axes. The instrument was equipped with an 
Oxford Instruments LZ5 windowless energy dispersive X-ray spectrometer (EDS) controlled by INCA. It had facilities for point analysis as well as mapping and line scanning through the SemiStem controller.

Catalyst activation was optimized using TPR-TPO redox treatment. To simulate the activation process, the first TPR experiments used $100 \% \mathrm{H}_{2}$ (wet or dry) as reducing gas, at $15 \mathrm{ml} / \mathrm{min}$ to give a GHSV $\sim 9,000 \mathrm{~h}^{-1}$. After the first TPR treatment, the catalyst was then oxidized with approximately $\mathrm{O}_{2} 5 \mathrm{vol} \%$ in helium using temperature programmed oxidation. After the first round TPR-TPO, the other TPR experiments adopted $5.02 \% \mathrm{H}_{2} /$ $\mathrm{He} 50 \mathrm{ml} / \mathrm{min}$ at $1{ }^{\circ} \mathrm{C} / \mathrm{min}$ temperature ramp rate to the final reduction temperature and time.

The TPO experiments were carried out using $5.02 \% \mathrm{O}_{2} /$ $\mathrm{He}$ as oxidizing gas, the temperature ramping rate was set at $5{ }^{\circ} \mathrm{C} / \mathrm{min}$ temperature ramp rate, $400{ }^{\circ} \mathrm{C}$ for $2 \mathrm{~h}$. During the cobalt oxide catalyst reduction, there was steam vapor generated, which may affect the cobalt particle and catalyst structure. So in this work, water vapor was co-fed with the hydrogen stream. The experimental details with water vapor are as follows:

The chemisorption machine was modified for co-feeding water vapor with hydrogen stream. $\mathrm{H}_{2}$ passes through the water saturator under controlled temperature to generate water vapor-saturated $\mathrm{H}_{2}$ stream for catalyst reduction during first TPR. The water saturator was set at $30{ }^{\circ} \mathrm{C}$ to generate $4.2 \% \mathrm{H}_{2} \mathrm{O} / \mathrm{H}_{2}$ stream.

The crystalline structure of the catalyst was analyzed using X-ray diffraction (Philips X-PeRT Pro Alpha I) operating with $\mathrm{Cu}_{\mathrm{K}} \alpha$ radiation $(\lambda=1.5406 \AA)$ at a tube current of $40 \mathrm{~mA}$ and a voltage of $45 \mathrm{kV}$ with speed of $0.02 / \mathrm{S}$.

\section{Results and discussion}

\section{Catalyst test}

The catalysts prepared with and without urea in the aqueous solution were tested for Fischer-Tropsch synthesis, and the results are shown in Figs. 1 and 2. It is noted that the relatively sharp change of the activity and selectivity is the consequence of the empty liquid trap which caused pressure change, but this does not change the general trend of the catalyst performance.

For the $\mathrm{Co} / \mathrm{SiO}_{2}-\mathrm{ZrO}_{2}-\mathrm{IC}$ catalysts, the $\mathrm{CO}$ conversion is about $67 \%$ at the start of reaction at $220{ }^{\circ} \mathrm{C}, 8$ bar with GHSV of $1,500 \mathrm{~h}^{-1}$, but the CO conversion decreases rapidly in the first $8 \mathrm{~h}$ and then gradually drops to $58 \%$ in $50 \mathrm{~h}$ time on stream, suggesting that the catalyst activity decreases; it is not stable, although the $\mathrm{C}_{5}{ }^{+}$selectivity is about $75 \%$ and almost remains unchanged during the test.

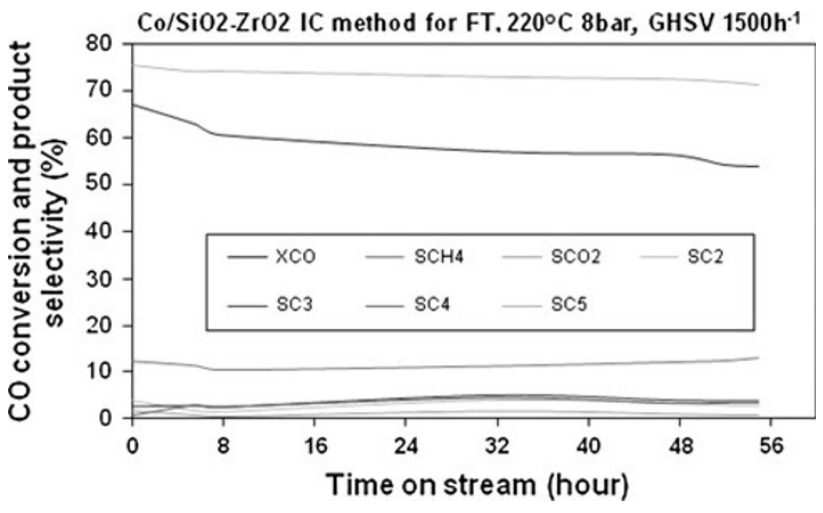

Fig. 1 FT test results of the $\mathrm{Co} / \mathrm{SiO}_{2}-\mathrm{ZrO}_{2}-\mathrm{IC}$

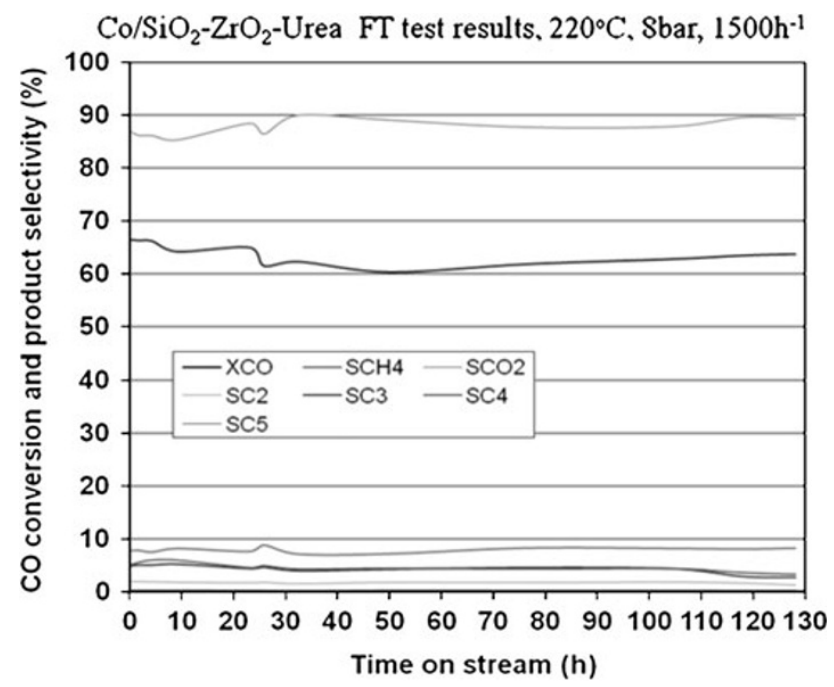

Fig. 2 FT test results of the $\mathrm{Co} / \mathrm{SiO}_{2}-\mathrm{ZrO}_{2}$-urea

The methane selectivity is more than $10 \%$ and slightly increase after the catalyst is tested for $50 \mathrm{~h}$.

Over the $\mathrm{Co} / \mathrm{SiO}_{2}-\mathrm{ZrO}_{2}$-urea catalyst under the same conditions, $\mathrm{CO}$ conversion is $67 \%$ at the start of time on stream, and gradually decreases to $61 \%$ in the first $10 \mathrm{~h}$, and then becomes stable afterward. Compared to the catalyst prepared without urea, the catalyst prepared with urea has the following advantages: the CO conversion keeps above $62 \%$ in the $180 \mathrm{~h}$ of time on stream, and the selectivity to $\mathrm{C}_{5}{ }^{+}$is about $90 \%$, and remains almost unchanged, the methane selectivity is less than $10 \%$.

Comparison of Figs. 1 and 2 suggests that the silica supported catalyst prepared with urea clearly has higher stability, and better selectivity to $\mathrm{C}_{5}{ }^{+}$. The addition of urea in the cobalt nitrate impregnation stage improves the Co particles' dispersion over the silica support.

The differently prepared catalysts' properties are shown in Table 1. It is shown that the loading of the cobalt oxide over the silica support decreased the catalyst surface area from $652 \mathrm{~m}^{2} / \mathrm{g}$ to about $350 \mathrm{~m}^{2} / \mathrm{g}$, and the pore size and 
Table 1 The physical properties of the different prepared Co catalysts

\begin{tabular}{lllllll}
\hline Support & $\begin{array}{l}\text { Calcination } \\
\mathrm{T}{ }^{\circ} \mathrm{C}\end{array}$ & $\begin{array}{l}\mathrm{BET} \mathrm{SA} \\
\left(\mathrm{m}^{2} / \mathrm{g}\right)\end{array}$ & $\begin{array}{l}\mathrm{PV} \\
\left(\mathrm{cm}^{3} / \mathrm{g}\right)\end{array}$ & $\begin{array}{l}\text { Pore size } \\
(\mathrm{nm})\end{array}$ & $\begin{array}{l}\mathrm{Co}_{3} \mathrm{O}_{4} \\
\text { particle size }\end{array}$ & $\begin{array}{l}\text { Reduced Co particle } \\
\text { size }(\mathrm{nm})\end{array}$ \\
\hline $\mathrm{SiO}_{2}$ support & 350 & 652 & 1.65 & 16 & & \\
$\mathrm{Co}_{3} \mathrm{O}_{4} / \mathrm{SiO}_{2}-\mathrm{ZrO}_{2}$ IC & 350 & 345 & 1.31 & 14.0 & 19.5 & 15 \\
$\mathrm{Co}_{3} \mathrm{O}_{4} / \mathrm{SiO}_{2}-\mathrm{ZrO}_{2}$ urea & 350 & 375 & 1.32 & 13.4 & 13.3 & 10.2 \\
\hline
\end{tabular}
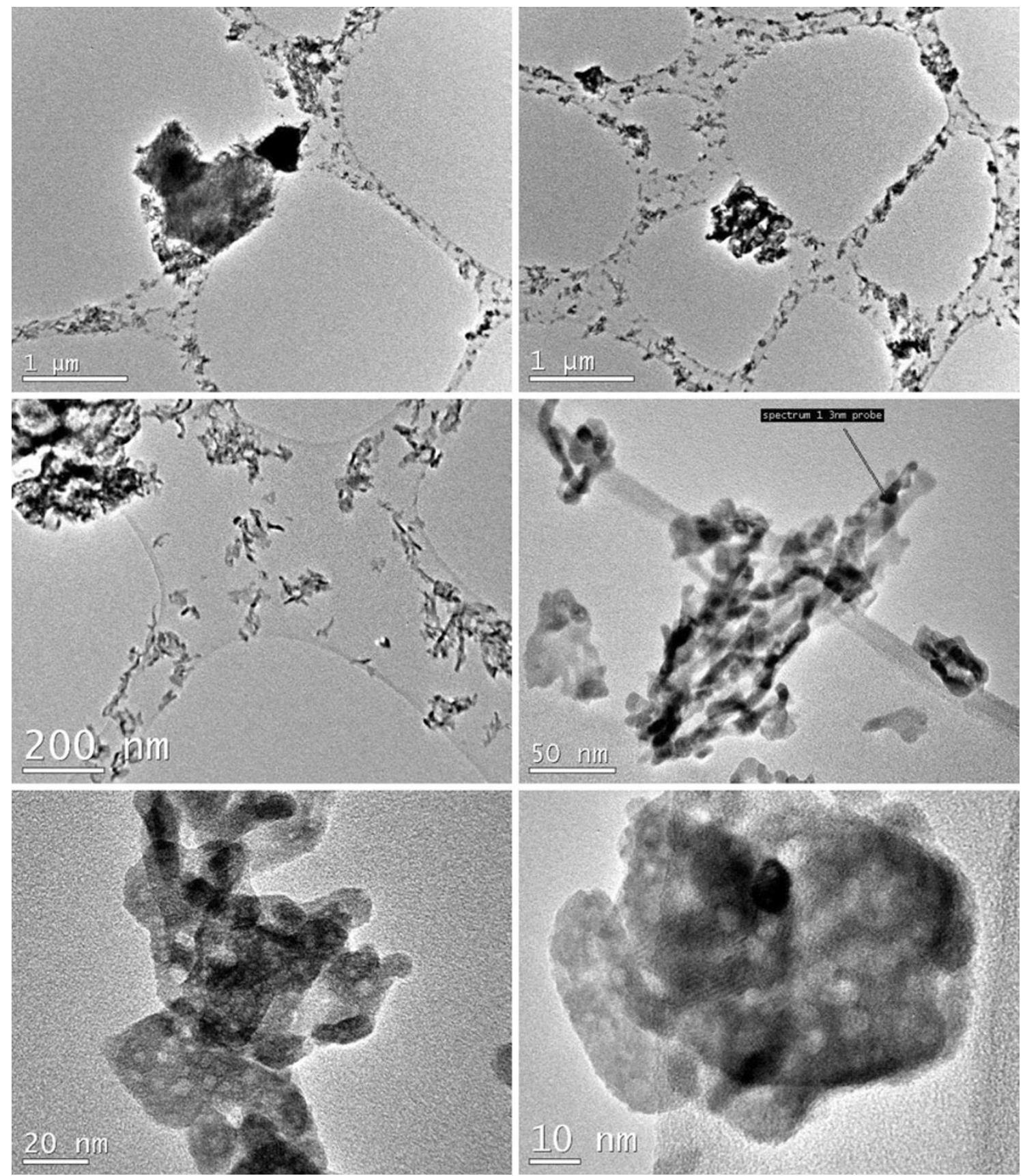

Fig. 3 The TEM image of $\mathrm{Co} / \mathrm{SiO}_{2}-\mathrm{ZrO}_{2}$ catalysts prepared without urea

pore volume all drop accordingly; this may be due to the fact that cobalt particle occupies the pores and wall of the pore of the support. The cobalt particles before and after reduction were measured using TEM and XRD; it is shown that the main phase of cobalt over the catalyst before activation in the $\mathrm{Co} / \mathrm{SiO}_{2}-\mathrm{ZrO}_{2}-\mathrm{IC}$ is $19.5 \mathrm{~nm}$, and that 

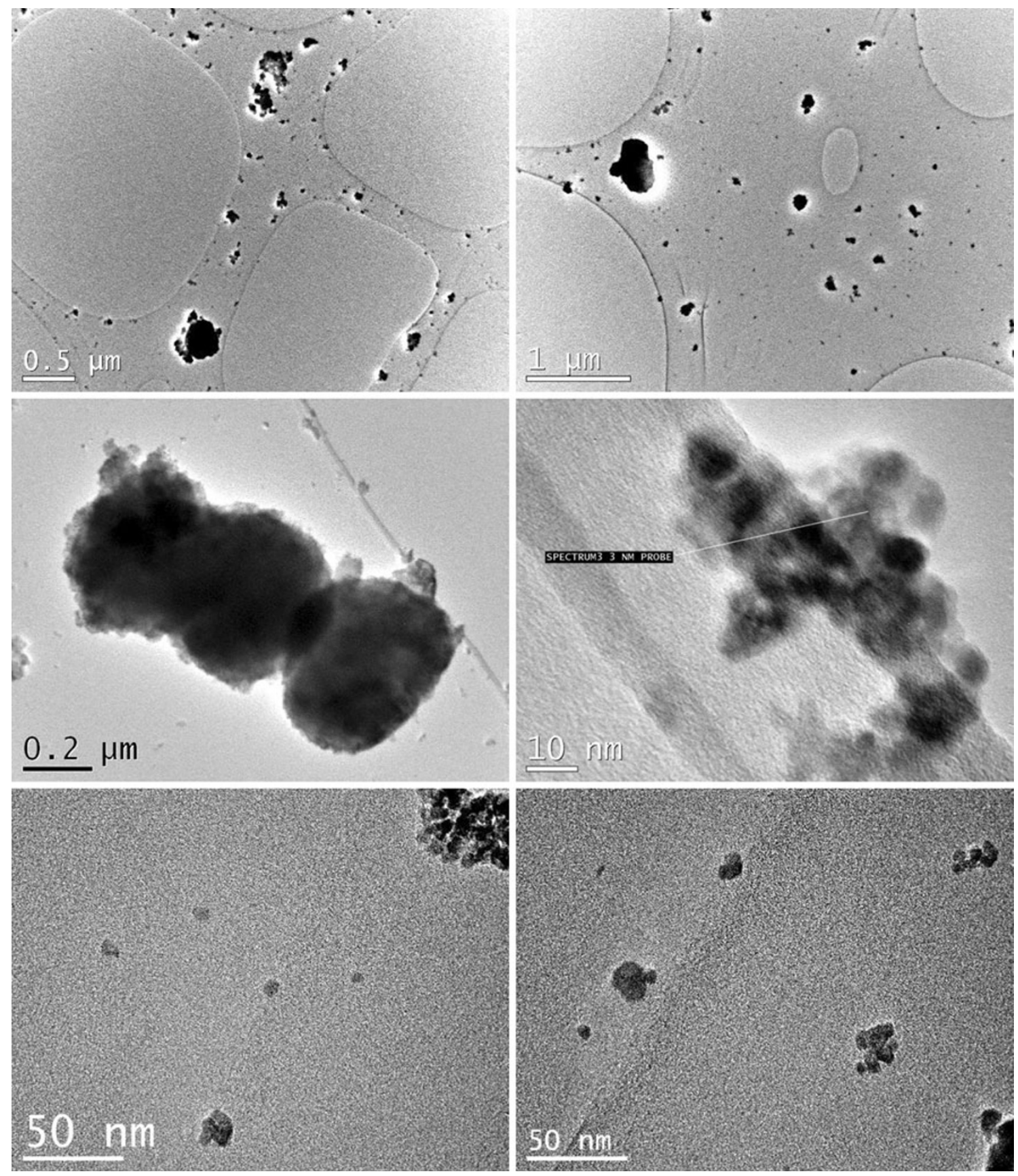

Fig. 4 TEM images of the $\mathrm{Co} / \mathrm{SiO}_{2}-\mathrm{ZrO}_{2}$-urea catalyst prepared using urea melted method after calcinations at $350{ }^{\circ} \mathrm{C}$

Table 2 TPO and BET data of the TPO-TPR treated catalysts

\begin{tabular}{llll}
\hline Run & $\begin{array}{l}\text { TPO peak } \\
\text { temperature }\left({ }^{\circ} \mathrm{C}\right)\end{array}$ & $\begin{array}{l}\mathrm{O}_{2} \text { uptake } \\
(\mathrm{cm} 3\end{array}$ & $\begin{array}{l}\text { BET surface } \\
\text { area }\left(\mathrm{m}^{2} / \mathrm{g}\right)\end{array}$ \\
\hline $\mathrm{TPO}_{1}$ & 182.5 & 63.06 & - \\
$\mathrm{TPO}_{2}$ & 165.7 & 57.87 & - \\
$\mathrm{TPO}_{3}$ & 161.9 & 57.10 & - \\
$\mathrm{TPO}_{4}$ & 160.1 & 55.78 & $284.6 \pm 1.2$ \\
\hline
\end{tabular}

over the urea containing catalyst $\mathrm{Co} / \mathrm{SiO}_{2}-\mathrm{ZrO}_{2}$-urea is $13.3 \mathrm{~nm}$. After the hydrogen reduction of the catalyst, cobalt is converted into cobalt metal, which changes to $15 \mathrm{~nm}$ over the $\mathrm{Co} / \mathrm{SiO}_{2}-\mathrm{ZrO}_{2}-\mathrm{IC}$ and $10.2 \mathrm{~nm}$ over $\mathrm{Co} /$ $\mathrm{SiO}_{2}-\mathrm{ZrO}_{2}$-urea. This suggests that the addition of urea during the catalyst preparation can help have a higher dispersion of the cobalt oxide and cobalt metal over the silica supported catalyst. 
Fig. 5 TPO results of the $\mathrm{Co} / \mathrm{SiO}_{2}-\mathrm{ZrO}_{2}$-urea during the TPR-TPO cycle treatment; double lines indicate the reproducibility of the TPR-TPO setup

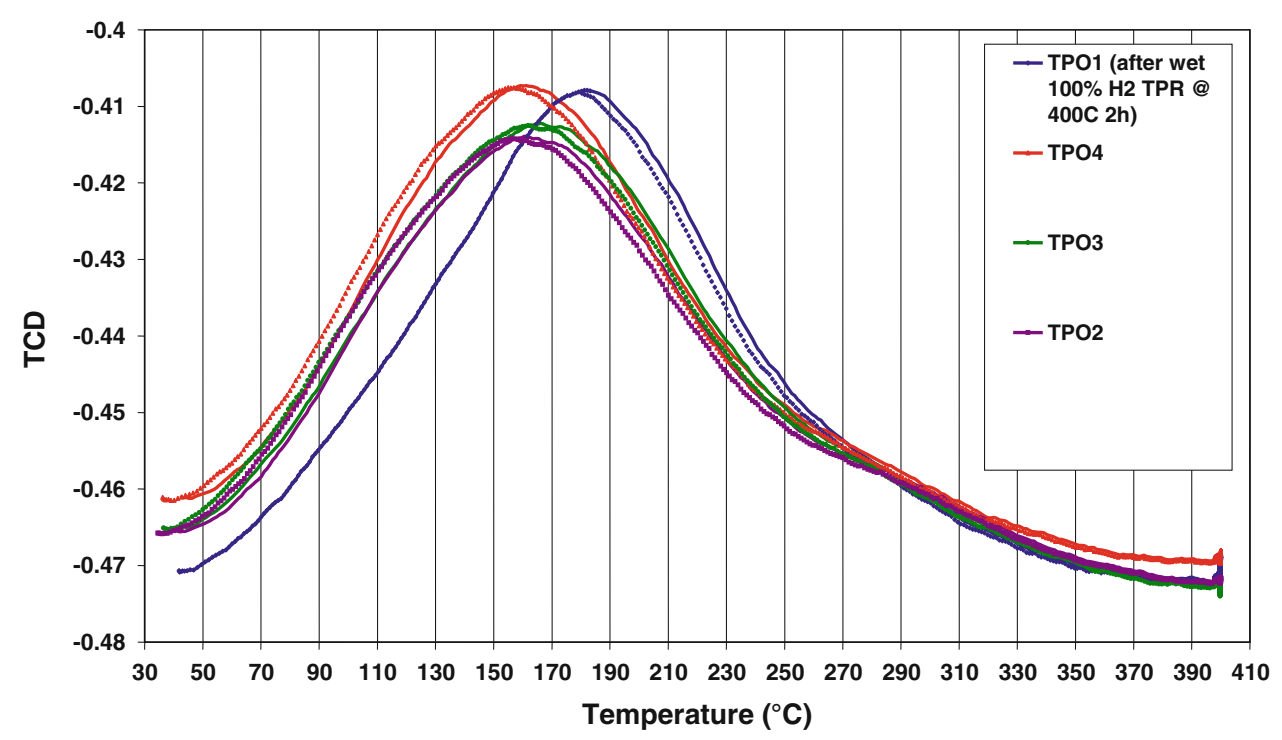

Table 3 TPR data of $\mathrm{Co} / \mathrm{SiO}_{2}-\mathrm{ZrO}_{2}$-urea

\begin{tabular}{lll}
\hline Run & TPR peak temperature $\left({ }^{\circ} \mathrm{C}\right)$ & Total $\mathrm{H}_{2}$ uptake $\left(\mathrm{cm}^{3} \mathrm{STP} / \mathrm{g}\right)^{\mathrm{a}}$ \\
\hline $\mathrm{TPR}_{2}$ & $129.6 / 246.0$ & 167.57 \\
$\mathrm{TPR}_{3}$ & $133.3 / 235.2$ & 168.92 \\
$\mathrm{TPR}_{4}$ & $134.8 / 235.9$ & 170.28
\end{tabular}

a TPR integration is not as accurate as TPO due to the fact of coldtrap warm up with time and the disturbance of profile, while changing cold trap during the run

\section{Characterization of the catalysts prepared} with and without urea using TEM

To study the effect of urea on the catalyst preparation and explore the catalytic differences between $\mathrm{Co} / \mathrm{SiO}_{2}-\mathrm{ZrO}_{2}-\mathrm{IC}$ and $\mathrm{Co} /$ $\mathrm{SiO}_{2}-\mathrm{ZrO}_{2}$-urea, the catalyst after calcinations has been characterized using TEM, and the results are shown in Figs. 3 and 4.
For the silica supported cobalt catalyst without adding urea, after drying before the calcination, XRD measurement showed that the cobalt is partly dehydrated to cobalt nitrate, the cobalt nitrate hydrate re-crystallizes when the water is vaporized even when it is dispersed in the high surface area support.

For the catalyst supported with urea added in the Co nitrate solution, where much excessive urea is added to form a melt urea- $\mathrm{Co}\left(\mathrm{NO}_{3}\right)_{2}$ solution, it is impregnated with the silica support and the mixture is dried at $50{ }^{\circ} \mathrm{C}$ for $6 \mathrm{~h}$, and the XRD results of the dried sample show no diffraction peaks, suggesting that the cobalt nitrate did not recrystallize when co-impregnated with urea.

The TEM observation results revealed that most particles in the $\mathrm{Co} / \mathrm{SiO}_{2}-\mathrm{ZrO}_{2}-\mathrm{IC}$ were small aggregates $(10-100 \mathrm{~nm})$ of elongated primary particles. Some micrometer-sized aggregates could also be seen. Many of
Fig. 6 TPR profiles of the $\mathrm{Co} / \mathrm{SiO}_{2}-\mathrm{ZrO}_{2}$-urea catalyst during the TPR-TPO cycles treatment with the wet hydrogen

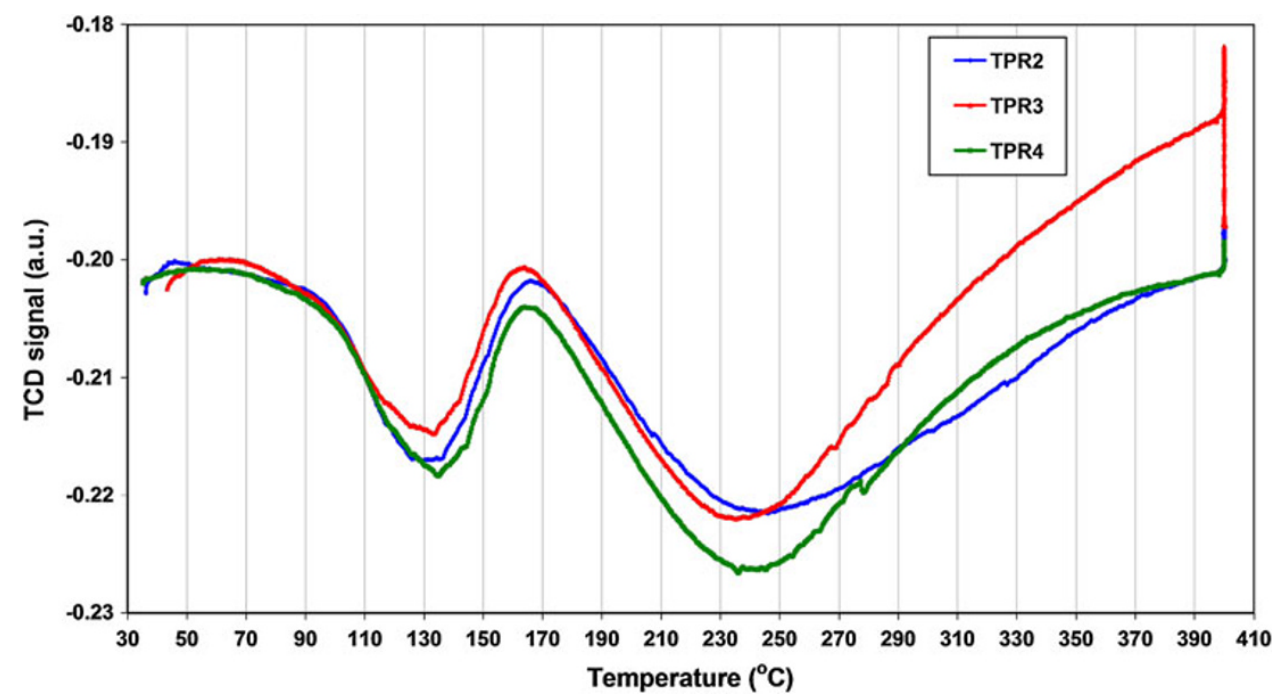


Table 4 TPO and BET data

\begin{tabular}{llll}
\hline Run & $\begin{array}{l}\text { TPO peak } \\
\text { temperature }\left({ }^{\circ} \mathrm{C}\right)\end{array}$ & $\begin{array}{l}\mathrm{O}_{2} \text { uptake } \\
\left(\mathrm{cm}^{3} \mathrm{STP} / \mathrm{g}\right)\end{array}$ & $\begin{array}{l}\text { BET surface area } \\
\left(\mathrm{m}^{2} / \mathrm{g}\right)\end{array}$ \\
\hline $\mathrm{TPO}_{1}$ & 172.5 & 65.55 & - \\
$\mathrm{TPO}_{2}$ & 163.8 & 59.65 & - \\
$\mathrm{TPO}_{3}$ & 166.7 & 61.02 & $282.0 \pm 1.2$ \\
\hline
\end{tabular}

the cobalt oxide particles are needle like, which are very close to the cobalt nitrate precursor crystallites. It is also found that small aggregates and single particles are in crystalline form, the broad particle size distribution may be the reason for the relatively low selectivity [7, 14, 35]. EDX studies with a $3-\mathrm{nm}$ probe gave a Co to $\mathrm{O}$ ratio of approx. 55-45\%.

The $\mathrm{Co} / \mathrm{SiO}_{2}-\mathrm{ZrO}_{2}$-urea sample has different TEM observation from the $\mathrm{Co} / \mathrm{SiO}_{2}-\mathrm{ZrO}_{2}-\mathrm{IC}$. Most particles over the urea melted catalysts have small aggregates (diameter 5-50 nm), but some micrometer-sized aggregates could also be seen. Compared to the Co nitrate sample without urea, these aggregates appear more isometrical and generally more single particles could be seen. Small aggregates and single particles are in crystalline form, but smaller than the conventional impregnated method, and with some potential porosity in the particle. The EDX studies of $3 \mathrm{~nm}$ probes gave a Co to $\mathrm{O}$ atomic ratio of $58-42 \%$, suggesting that some cobalt might be reduced by the urea during the calcinations.

Figures 1 and 2 showed that the urea melting method gave higher FT catalyst stability and $\mathrm{C}_{5}{ }^{+}$selectivity. Given that much more excessive urea is added in the catalyst preparation, there maybe some amount of carbon residue in the catalyst, which may be removed by TPOTPR treatment, it has also been shown that the TPO-TPR cycle treatment of the cobalt catalyst can increase the catalyst dispersion [36-38]. And for the cobalt catalyst prepared using urea melt cobalt salt method, the optimization of the catalyst activation may be able to improve the catalyst performance. To reach a better catalyst performance, therefore in the following work, we will employ TPR-TPO treatment of the $\mathrm{Co} / \mathrm{SiO}_{2}-\mathrm{ZrO}_{2}$-urea and to characterize the catalyst $\mathrm{Co}$ dispersion and $\mathrm{H}_{2}$ pickup so as to explore the optimized conditions for the catalyst activation.

TPO/TPR cycle study for catalyst activation optimization

Wet $\mathrm{H}_{2} \mathrm{TPR}_{1}\left(400{ }^{\circ} \mathrm{C} 2 \mathrm{~h}\right)$ followed by $\mathrm{TPO}_{1} / \mathrm{TPR}_{2} / \mathrm{TPO}_{2} /$ $\mathrm{TPR}_{3} / \mathrm{TPO}_{3} / \mathrm{TPR} / \mathrm{TPO} \mathrm{O}_{4}$

This experiment was performed by wet $\mathrm{H}_{2}$ reduction $\left(\mathrm{TPR}_{1}: \mathrm{H}_{2} \mathrm{GHSV}=8,740 \mathrm{~h}^{-1}, 4.2\right.$ vol $\left.\% \mathrm{H}_{2} \mathrm{O}\right)$ followed by normal TPO/TPR as described above. The TPO results are presented in Table 2 and Fig. 5. The TPR results are presented in Table 3 and Fig. 6.

It is seen that the $\mathrm{TPO}_{1}$ after wet $\mathrm{H}_{2}$ reduction shows higher TPO peak temperature and more $\mathrm{O}_{2}$ uptake than the sequential TPOs. $\mathrm{TPO}_{2}, \mathrm{TPO}_{3}$ and $\mathrm{TPO}_{4}$ have similar peak temperature and $\mathrm{O}_{2}$ uptake, but all of them are lower than $\mathrm{TPO}_{1}$. The oxidation peak temperatures of $\mathrm{TPO}_{2}, \mathrm{TPO}_{3}$ and $\mathrm{TPO}_{4}$ are also lower than $\mathrm{TPO}_{1}$. These results suggest that the first pure $\mathrm{H}_{2} / \mathrm{H}_{2} \mathrm{O}$ reduction reduce more cobalt oxide into cobalt metal with bigger particle size, and the followed oxidation, then $5 \% \mathrm{H}_{2} / \mathrm{Ar}$ reduction may further reduce the particle size, which becomes easier to be oxidized. But the reduction gas stream, e.g., 5 vol $\% \mathrm{H}_{2}$ may not be able to reduce the cobalt oxide into metal, hence it has less $\mathrm{O}_{2}$ pickup in the followed TPO cycles.
Fig. 7 TPOs profiles of the $\mathrm{Co} / \mathrm{SiO}_{2}-\mathrm{ZrO}_{2}$-urea catalyst firstly reduced with dry hydrogen (no water vapor is brought in with $\mathrm{H}_{2}$ )
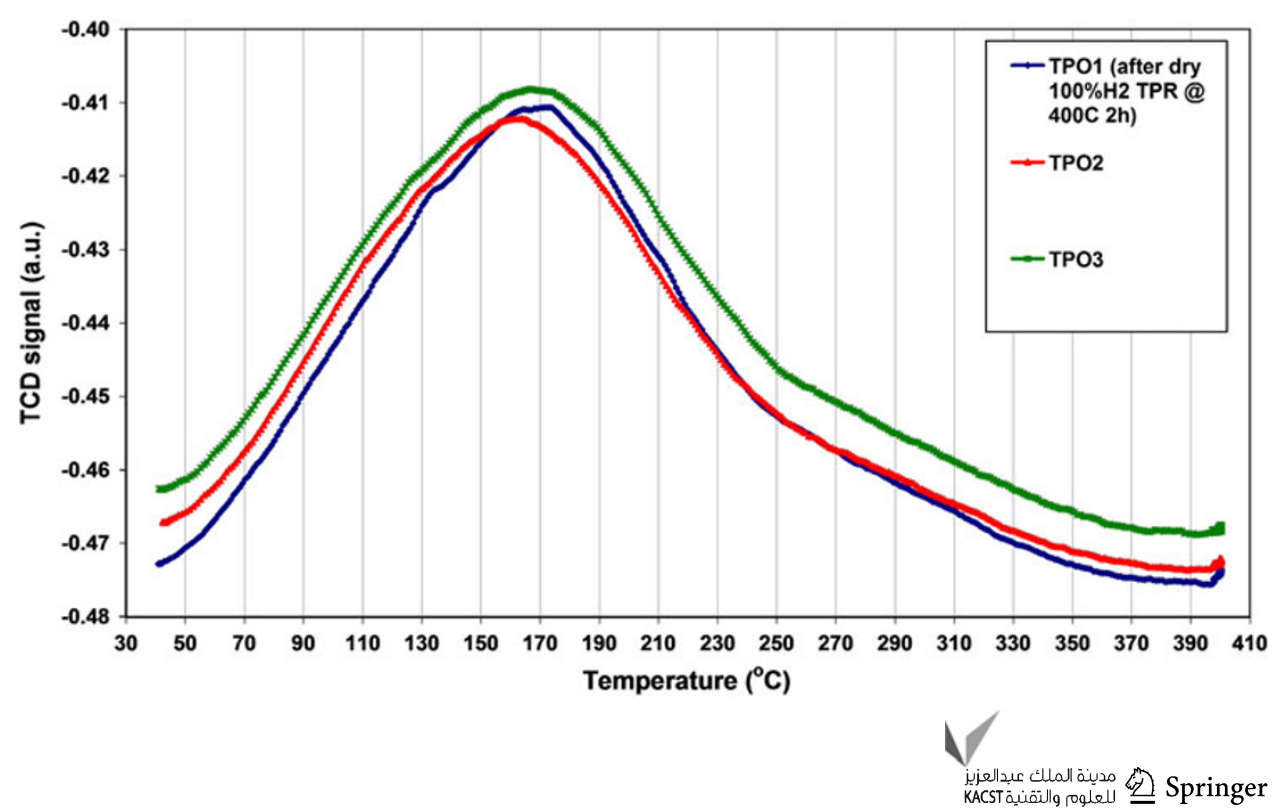
Table 5 TPR data

\begin{tabular}{lll}
\hline Run & $\begin{array}{l}\text { TPR peak } \\
\text { temperature }\left({ }^{\circ} \mathrm{C}\right)\end{array}$ & $\begin{array}{l}\text { Total } \mathrm{H}_{2} \text { uptake } \\
\left(\mathrm{cm}^{3} \mathrm{STP} / \mathrm{g}\right)\end{array}$ \\
\hline $\mathrm{TPR}_{2}$ & $130.1 / 239.2$ & 169.8 \\
$\mathrm{TPR}_{3}$ & $139.2 / 242.4$ & 200.8 \\
\hline
\end{tabular}

After wet $\mathrm{H}_{2}$ reduction cobalt is more difficult to reoxidize than that reduced under dry $5 \% \mathrm{H}_{2} / \mathrm{Ar}$. And there is more $\mathrm{Co}$ reduced in wet $\mathrm{H}_{2}$ reduction than consequential TPRs. This may be explained by the fact that the in the first wet-reduction, hydrogen is almost in pure stream, which can reduce more cobalt than the $\mathrm{TPR}_{2}$ that used $5 \mathrm{vol} \%$ of $\mathrm{H}_{2}$ in argon, the cobalt reduction may not be achieved completely with $5 \mathrm{vol} \% \mathrm{H}_{2} / \mathrm{Ar}$.

The surface area of the $\mathrm{Co} / \mathrm{SiO}_{2}-\mathrm{ZrO}_{2}$-urea changed to about $284.6 \mathrm{~m}^{2} / \mathrm{g}$ after the TPR-TPO cycle treatment, which might result from the cobalt oxide reduction.

It is to be noted that $\mathrm{TPR}_{1}$ is not shown here, because it is carried out in pure hydrogen stream at temperature programmed way; however, the TCD detector cannot respond to the change of pure hydrogen stream, no report of $\mathrm{TPR}_{1}$ is given.

In the TPR profiles of the $\mathrm{Co} / \mathrm{SiO}_{2}-\mathrm{ZrO}_{2}$-urea during the TPR-TPO cycle treatment, we can see that $\mathrm{TPR}_{2}$ shows lower peak temperatures and less $\mathrm{H}_{2}$ uptake than $\mathrm{TPR}_{3}$ and $\mathrm{TPR}_{4} \cdot \mathrm{TPR}_{3}$ and $\mathrm{TPR}_{4}$ show similar peak temperatures. However, after TPR/TPO treatment cycles, the first cobalt reduction peak temperature shifts slightly higher, while the second cobalt reduction peak temperature shifts lower. This suggests that the overall cobalt interaction with support may be weak; however, some cobalt particles may become smaller, hence the first reduction peaks shift upwards.
It is interesting to see that after the redox treatment, $\mathrm{H}_{2}$ uptake amount is significantly higher, suggesting that cobalt dispersion increases after the treatment.

Dry $\mathrm{H}_{2} \mathrm{TPR}_{1}\left(400^{\circ} \mathrm{C} 2 \mathrm{~h}\right)$ followed by $\mathrm{TPO}_{1} / \mathrm{TPR}_{2} / \mathrm{TPO}_{2} /$ $\mathrm{TPR}_{3} / \mathrm{TPO}_{3}$

This experiment was performed by dry $100 \% \mathrm{H}_{2}$ reduction $\left(\mathrm{TPR}_{1}: \mathrm{H}_{2} \mathrm{GHSV}=8,680 \mathrm{~h}^{-1}\right.$ ) followed by normal TPO/ TPR as described above. The TPO results are presented in Table 4 and Fig. 7. The TPR results are presented in Table 5 and Fig. 8.

We can see that the $\mathrm{TPO}_{1}$ after dry $100 \% \mathrm{H}_{2}$ reduction shows higher peak temperature and more $\mathrm{O}_{2}$ uptake than the sequential TPOs. $\mathrm{TPO}_{2}$ shows lower peak temperature and less $\mathrm{O}_{2}$ uptake than $\mathrm{TPO}_{3}$. This result is very similar to that of wet $\mathrm{H}_{2}$ reduction; however, $\mathrm{TPO}_{1}$ peak temperature is about $10{ }^{\circ} \mathrm{C}$ lower than wet $\mathrm{H}_{2}$ reduction case. And the higher $\mathrm{O}_{2}$ uptake in $\mathrm{TPO}_{1}$ of the dried $\mathrm{H}_{2}$ reduced sample $\left(65.55 \mathrm{~cm}^{3} \mathrm{STP} / \mathrm{g}\right)$ is due to the better reducibility of the dry-hydrogen stream.

Although the peak temperature of $\mathrm{TPO}_{3}$ shifts a little higher, it is still lower than $\mathrm{TPO}_{1}$, suggesting that the redox treatment makes it easier for cobalt metal to be oxidized.

It is seen that $\mathrm{TPR}_{2}$ shows lower peak temperatures and less total $\mathrm{H}_{2}$ uptake than $\mathrm{TPR}_{3}$. This is not consistent with the one pre-reduced with wet-hydrogen stream. In the wethydrogen treatment catalyst, the first cobalt reduction peaks shifts to higher temperature, which is similar to the dryhydrogen system; however, the second cobalt reduction peak maxima temperature shifts to lower end, which easily reduces the catalyst completely. The higher $\mathrm{H}_{2}$ uptake of $\mathrm{TPR}_{3}$ suggests that the redox treatment significantly increases the cobalt dispersion.
Fig. 8 TPRs profiles of the $\mathrm{Co} / \mathrm{SiO}_{2}-\mathrm{ZrO}_{2}$-urea firstly reduced with dry $\mathrm{H}_{2}$ and then TPO-TPR cycle treatment

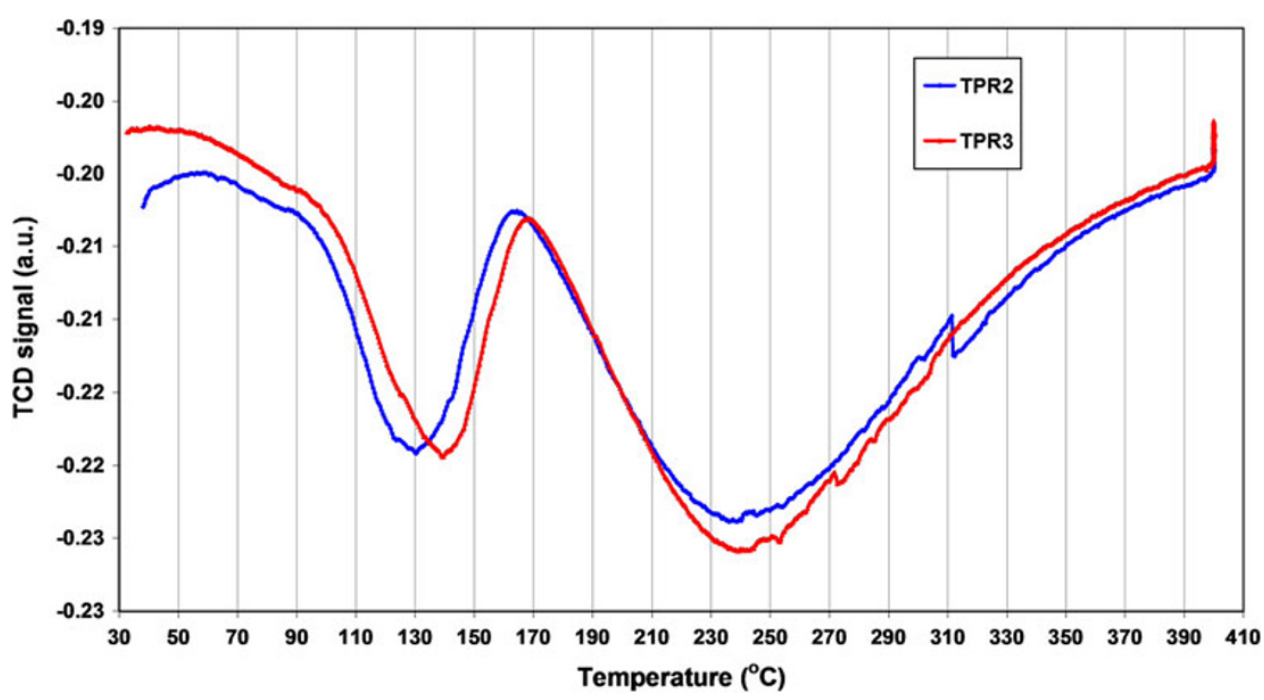


Table 6 Comparison of the effect of redox treatment on the FT performance of the $\mathrm{Co} / \mathrm{SiO}_{2}-\mathrm{ZrO}_{2}$-urea catalyst

\begin{tabular}{llll}
\hline $\begin{array}{l}\text { Catalyst } \\
\text { treatment }\end{array}$ & $\begin{array}{l}\text { Dry } \mathrm{H}_{2} \\
\text { reduction } \\
\text { to } 400{ }^{\circ} \mathrm{C}\end{array}$ & $\begin{array}{l}\text { Redox with } \\
\text { wet } \mathrm{H}_{2} \\
\text { (water vapor) }\end{array}$ & $\begin{array}{l}\text { Reduced with dry } \\
\text { hydrogen, then three } \\
\text { cycles redox } \\
\text { treatment }\end{array}$ \\
\hline $\mathrm{CO}$ conversion (\%) & 63.6 & 65.2 & 64.1 \\
$\mathrm{C}_{5}{ }^{+}$selectivity (\%) & 88.6 & 89.1 & 88.9 \\
$\mathrm{CH}_{4}$ selectivity & 8.3 & 8.4 & 8.3 \\
\hline
\end{tabular}

Catalyst test conditions: $220{ }^{\circ} \mathrm{C}, 8 \mathrm{bar}$, GHSV $1,200 \mathrm{~h}^{-1}, \mathrm{H}_{2} /$ $\mathrm{CO}=2: 1$, the data were obtained after $20 \mathrm{~h}$ time on stream

Also the cobalt dispersion in the dry-hydrogen treated system is higher than that in the wet-hydrogen pre-treated system.

Table 6 shows the catalyst test results of the $\mathrm{Co} / \mathrm{SiO}_{2}-$ $\mathrm{ZrO}_{2}$-urea using different activation methods, it is also shows that the redox treatment leads to different $\mathrm{H}_{2}$ pickup and the reduction temperatures, the $\mathrm{CO}$ conversion only slightly increases with the water vapor-containing $\mathrm{H}_{2}$ and then redox treatment, changing from 63.1 to $65.2 \%$ of $\mathrm{CO}$ conversion, while the dry $\mathrm{H}_{2}$ treatment catalyst increases less Co conversion than the water vapor-containing $\mathrm{H}_{2}$ stream. In terms of $\mathrm{C}_{5}{ }^{+}$selectivity, there are little differences; all the catalysts with different activation have $\mathrm{C}_{5}{ }^{+}$ selectivity of $90 \%$. These results suggest that the activation with redox treatment may have a little improvement on the catalyst activity, but with almost no effects on the product selectivity.

\section{Conclusion}

1. Silica supported Co catalysts promoted with $\mathrm{ZrO}_{2}$ have been prepared with and without urea addition to the cobalt solution. It is shown that the catalyst prepared with urea added to the cobalt precursor has higher activity for Co conversion and $\mathrm{C}_{5}{ }^{+}$selectivity under the test conditions. Also the catalyst is more stable.

2. TEM results showed that the addition of urea in the cobalt solution makes cobalt oxide particle smaller and more uniform. The main phase of cobalt after the calcinations is $\mathrm{Co}_{3} \mathrm{O}_{4}$.

3. In the catalyst activation of $\mathrm{Co} / \mathrm{SiO}_{2}-\mathrm{ZrO}_{2}$-urea, the initial reduction conditions using $100 \% \mathrm{H}_{2}$ have a significant effect on following $\mathrm{TPO}_{1}$. The effect on $\mathrm{TPO}_{1}$ peak temperature follows the order: "wet $100 \% \mathrm{H}_{2} \quad 400{ }^{\circ} \mathrm{C} 2 \mathrm{~h}\left(182.5{ }^{\circ} \mathrm{C}\right) ">$ dry $100 \% \mathrm{H}_{2}$ $400{ }^{\circ} \mathrm{C} 2 \mathrm{~h}\left(172.5{ }^{\circ} \mathrm{C}\right)$.

4. The pre-reduction atmosphere has effect on the cobalt reduction after TPO treatment. When water vapor is present in the hydrogen stream, the first $\mathrm{H}_{2}$ TPR peak shifts to higher temperature, but the second $\mathrm{H}_{2}$ TPR peaks shifts to lower temperature after redox treatment. When dry hydrogen is used for pre-reduction, both TPR $\mathrm{H}_{2}$ reduction peaks shift to higher temperature.

5. Redox cycle treatment leads to higher cobalt dispersion, which is reflected by the increase of $\mathrm{H}_{2}$ uptake in the $\mathrm{TPR}_{2}$ files. The dry $\mathrm{H}_{2}$ reduced at $400{ }^{\circ} \mathrm{C}$ gives the highest cobalt dispersion after two cycles of redox treatment, while pre-treatment with wet hydrogen gives the lowest $\mathrm{H}_{2}$ uptake after the two cycles of redox treatment.

6. Although redox treatment helps increase the reducibility of the cobalt in the catalyst, the catalyst performance improvement is not so significant, there is slightly better $\mathrm{CO}$ conversion, while the $\mathrm{C}_{5}{ }^{+}$selectivity remains almost unchanged among the catalyst.

Open Access This article is distributed under the terms of the Creative Commons Attribution License which permits any use, distribution, and reproduction in any medium, provided the original author(s) and the source are credited.

\section{References}

1. Lamprecht D (2007) Fischer-Tropsch fuel for use by the U.S. military as battlefield-use fuel of the future. Energy Fuels 21(3):1448-1453

2. Simonetti DA, Dumesic JA (2008) Catalytic strategies for changing the energy content and achieving $\mathrm{C}-\mathrm{C}$ coupling in biomass-derived oxygenated hydrocarbons. Chem Sus Chem 1(8-9):725-733

3. Srinivas S, Malik RK, Mahajani SM (2009) Feasibility of reactive distillation for Fischer-Tropsch synthesis. 2. Ind Eng Chem Res 48(10):4710-4718

4. Kreutz TG et al (2008) Fischer-Tropsch fuels from coal and biomass. Proc Annu Int Pittsburgh Coal Conf 25th: pp 303/1-303/ 86

5. Searcy E, Flynn PC (2010) A criterion for selecting renewable energy processes. Biomass Bioenergy 34(5):798-804

6. Xiao T (2008) Preparation of super active cobalt based hydrogenation catalysts. Abstracts of Papers, 235th ACS National Meeting, New Orleans, LA, United States, April 6-10, 2008, p FUEL-079

7. de la Pena O'Shea VA et al (2006) Structural changes and activation treatment in a $\mathrm{Co} / \mathrm{SiO}_{2}$ catalyst for Fischer-Tropsch synthesis. Catal Today 114(4):422-427

8. Dutta P et al (2004) Characterization of Fischer-Tropsch cobaltbased catalytic systems $\left(\mathrm{Co} / \mathrm{SiO}_{2}\right.$ and $\left.\mathrm{Co} / \mathrm{Al}_{2} \mathrm{O}_{3}\right)$ by X-ray diffraction and magnetic measurements. Catal Lett 98(4):203-210

9. Hinchiranan $\mathrm{S}$ et al (2008) $\mathrm{TiO}_{2}$ promoted $\mathrm{Co} / \mathrm{SiO}_{2}$ catalysts for Fischer-Tropsch synthesis. Fuel Process Technol 89(4):455-459

10. Liotta $\mathrm{LF}$ et al (2008) $\mathrm{Co}_{3} \mathrm{O}_{4}$-based catalysts for $\mathrm{CO}$ and hydrocarbons oxidation: influence of the preparation method and chemical composition on structural and reactivity properties. Curr Top Catal 7:77-97

11. Ma X et al (2009) Effects of promoters on catalytic performance of $\mathrm{Fe}-\mathrm{Co} / \mathrm{SiO}_{2}$ catalyst for Fischer-Tropsch synthesis. J Nat Gas Chem 18(3):354-358 
12. Oh J-H et al (2009) Slurry-phase Fischer-Tropsch synthesis using $\mathrm{Co} / \gamma-\mathrm{Al}_{2} \mathrm{O}_{3}, \mathrm{Co} / \mathrm{SiO}_{2}$ and $\mathrm{Co} / \mathrm{TiO}_{2}$ : effect of support on catalyst aggregation. Catal Lett 130(3-4):403-409

13. Profeti LPR, Ticianelli EA, Assaf EM (2008) $\mathrm{Co} / \mathrm{Al}_{2} \mathrm{O}_{3}$ catalysts promoted with noble metals for production of hydrogen by methane steam reforming. Fuel 87(10-11):2076-2081

14. den Breejen JP et al (2010) Design of supported cobalt catalysts with maximum activity for the Fischer-Tropsch synthesis. J Catal 270(1):146-152

15. Liotta LF et al (2004) Structural and morphological investigation of a cobalt catalyst supported on alumina-baria: effects of redox treatments on the activity in the NO reduction by CO. Appl Catal B 52(1):1-10

16. Zhao Y et al (2012) SBA-16-supported cobalt catalyst with high activity and stability for Fischer-Tropsch synthesis. Chem Cat Chem 4(2):265-272

17. Zhou W et al (2008) Effects of methanol co-feeding in $\mathrm{F}-\mathrm{T}$ synthesis on a silica supported Co-catalyst. Fuel Process Technol 89(11):1113-1120

18. Mochizuki $\mathrm{T}$ et al (2008) Improvement of the Fischer-Tropsch synthesis activity of $\mathrm{Co} / \mathrm{SiO}_{2}$ catalyst by the stepwise impregnation method with chelating agents. Catal Lett 121(1-2):52-57

19. Zhang Y, Hanayama K, Tsubaki N (2006) The surface modification effects of silica support by organic solvents for FischerTropsch synthesis catalysts. Catal Commun 7(5):251-254

20. Xiao T, Qian Y (2008) Promoted carbide-based Fischer-Tropsch catalyst, method for its preparation and uses thereof, (Oxford Catalysts Limited, UK). Application: WO p 35

21. Bambal AS et al (2010) Influence of a chelating agent on activity of $\mathrm{SiO}_{2}$-supported cobalt catalyst in Fischer-Tropsch synthesis. Prepr Am Chem Soc Div Pet Chem 55(1):154-155

22. Koizumi N et al (2012) Mechanistic aspects of the role of chelating agents in enhancing Fischer-Tropsch synthesis activity of $\mathrm{Co} / \mathrm{SiO}_{2}$ catalyst: importance of specific interaction of Co with chelate complex during calcination. J Catal 289:151-163

23. Koizumi N, Mochizuki T, Yamada M (2009) Novel cluster-size dependent phenomenon in Fischer-Tropsch synthesis with $\mathrm{SiO}_{2}$ supported Co cluster catalyst. e-J. Surf Sci Nanotechnol 7:633-640

24. Koizumi N, Mochizuki T, Yamada M (2009) Preparation of highly active catalysts for ultra-clean fuels. Catal Today 141(1-2):34-42

25. Mochizuki T et al (2007) Novel preparation method of highly active $\mathrm{Co} / \mathrm{SiO}_{2}$ catalyst for Fischer-Tropsch synthesis with chelating agents. Catal Lett 113(3-4):165-169
26. Mochizuki T et al (2007) Surface structure and Fischer-Tropsch synthesis activity of highly active $\mathrm{Co} / \mathrm{SiO}_{2}$ catalysts prepared from the impregnating solution modified with some chelating agents. Appl Catal A 317(1):97-104

27. Xiao $\mathrm{T}$ et al (2005) Effect of promoters on the HDS performance of the supported catalysts prepared using OMXC method. Prepr Am Chem Soc Div Pet Chem 50(4):360-366

28. Xiao T, Moreau P, Zhao Y (2008) Preparation of super active cobalt based hydrogenation catalysts. Prepr Symp Am Chem Soc Div Fuel Chem 53(1):166-167

29. Green MLH, Xiao T (2003) Process for preparing catalysts for Fischer-Tropsch synthesis and steam reforming, (Isis Innovation Limited, UK). Application: WO p 39

30. Michalak A, Nowosielska M, Jozwiak WK (2009) Physico-chemical properties of cobalt-ruthenium $(10 \% \mathrm{Co}-0.5 \% \mathrm{Ru})$ catalysts supported on binary oxides $8.5 \% \mathrm{ZrO}_{2} / \mathrm{Support}\left(\mathrm{SiO}_{2}, \mathrm{Al}_{2} \mathrm{O}_{3}\right.$, $\mathrm{TiO}_{2}$ ) for Fischer-Tropsch synthesis. Top Catal 52(8):1044-1050

31. Pradier CM et al (2000) Supported chromia catalysts for oxidation of organic compounds the state of chromia phase and catalytic performance. Appl Catal B 27(2):73-85

32. Zhang Y, Yoneyama Y, Tsubaki N (2004) Development of bimodal cobalt catalysts for Fischer-Tropsch synthesis. Prepr Symp Am Chem Soc Div Fuel Chem 49(2):647-648

33. de la Pena O'Shea VA et al (2005) Strong dependence on pressure of the performance of a $\mathrm{Co} / \mathrm{SiO}_{2}$ catalyst in Fischer-Tropsch slurry reactor synthesis. Catal Lett 100(1-2):105-110

34. Zhang Y et al (2007) Effects of impregnation solvent on $\mathrm{Co} / \mathrm{SiO}_{2}$ catalyst for Fischer-Tropsch synthesis: a highly active and stable catalyst with bimodal sized cobalt particles. Appl Catal A 321(1):79-85

35. Prieto G et al (2009) Cobalt particle size effects in FischerTropsch synthesis: structural and in situ spectroscopic characterization on reverse micelle-synthesised Co/ITQ-2 zeolite catalysts. J Catal 266(1):129-144

36. Pan $\mathrm{Z}$ et al (2011) Pretreatment effect studies with $\mathrm{Co} / \mathrm{ZnO}$ catalyst in a fixed bed reactor. Abstracts of Papers, 241st ACS National Meeting \& Exposition, Anaheim, CA, United States, March 27-31, p FUEL-214

37. Pan Z, Bukur D (2012) Fischer-Tropsch synthesis on $\mathrm{Co} / \mathrm{Al}_{2} \mathrm{O}_{3}$ catalyst: Effects of activation and regeneration procedures. Abstracts of Papers, 243rd ACS National Meeting \& Exposition, San Diego, CA, United States, March 25-March 29, p PETR-51

38. Sewell GS, van Steen E, O'Connor CT (1996) Use of TPR/TPO for characterization of supported cobalt catalysts. Catal Lett $37(3,4): 255-60$ 